\title{
Research Paper: Modeling the Relationship Between Occupational Accidents, Work-Family Conflict, and Quality of Work-Life in Emergency Room Nurses
}

\author{
Leila Hefazi Torghabeh ${ }^{1}$, Mones Hosseini ${ }^{2 *}$ (D), Marzieh Soltani ${ }^{3}$ (D), Ali Jahanian ${ }^{4}$
}

1. Department of Educational Psychology, Faculty of Educational Sciences and Psychology, Alzahra University, Tehran, Iran

2. Department of Educational Psychology, Faculty of Educational Sciences and Psychology, Gachsaran Branch, Azad University, Gachsaran, Iran

3. Department of Counselling, Faculty of Educational Sciences and Psychology, West Tehran Branch, Islamic Azad University, Tehran, Iran.

4. Department of Counselling, Faculty of Educational Sciences and Psychology, Kharazmi University, Tehran, Iran.

\begin{tabular}{|c|c|}
\hline $\begin{array}{l}\text { Usse yourdevice to tsan } \\
\text { and read the article online }\end{array}$ & Chation Hefazi Torghabeh L, Hosseini M, Soltani M, Jahanian A. Modeling the Relationship Between Occupational Ac- \\
\hline 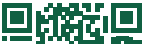 & cidents, Work-Family Conflict, and Quality of Work-Life in Emergency Room Nurses. Health in Emergencies and Disasters \\
\hline+4 & Quarterly. 2021; 6(4):245-250. http://dx.doi.org/10.32598/hdq.6.4.411.3 \\
\hline Dishat & dol : http://dx.doi.org/10.32598/hdq.6.4.411.3 \\
\hline
\end{tabular}

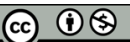

Article info:

Received: 03 May 2021

Accepted: 26 Jun 2021

Available Online: 01 Jul 2021

\section{Keywords:}

Occupational accident relationship, Quality of worklife, Work-family conflict, Emergency department

\section{ABSTRACT}

Background: This study aimed to model the relationship between occupational accidents, work-family conflict, and quality of work-life in emergency room nurses.

Materials and Methods: This correlational research uses path analysis. The study population consisted of all nurses working in the emergency rooms of hospitals in Tehran City, Iran, in 2020. Of them, 200 samples were selected by the available sampling method. To obtain the data, we used the occupational accidents questionnaire, the quality of work-life questionnaire, and the work-family conflict scale. SPSS v. 24 and Amos v. 24 software were used for data analysis.

Results: The analysis of the findings showed that occupational accidents and work-family conflict have a negative and direct effect on the quality of work-life $(\mathrm{P}<0.01)$. Occupational accidents also have a positive and direct effect on work-family conflict $(\mathrm{P}<0.01)$. On the other hand, the mediating role of work-family conflict between occupational accidents and quality of work-life was confirmed $(\mathrm{P}<0.01)$.

Conclusion: The relationship model of occupational accidents with quality of work-life mediated by work-family conflict has a good fit, and there is a relationship between family, job, and environmental stressors with the quality of work-life.

\section{Introduction}

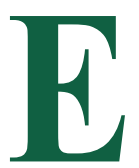

mergency Room (ER) nurses are exposed to stresses caused by emergencies and related factors that can affect their quality of life and work [1]. Paying attention to the quality of work-life of ER nurses positively affects their work performance [2].
Quality of work-life means creating a work environment in which nurses feel safe and happy, their personal and professional needs are met, they are satisfied with the work and living environment [3]. Quality of work-life also refers to the value and dignity of employees in the organization, their greater participation in the decisionmaking process, reducing family and work conflict, and creating an interaction between quality of work-life and

\section{"Corresponding Author:}

Mones Hosseini, PhD.

Address: Department of Educational Psychology, Faculty of Educational Sciences and Psychology, Gachsaran Branch, Azad University, Gachsaran, Iran.

E-mail:davodfathi95@gmail.com;davodfathi95@gmail.com 
employees' work environment [4]. Quality of life can be affected by environmental, work, and family factors.

Work accidents are one of the environmental and occupational components that can reduce the quality of work [5]. ER nurses and health care providers are among the high-risk groups in terms of contracting diseases and dealing with occupational accidents [6]. According to the US Department of Labor, more than 6000 accidents resulted in absenteeism and transfer from wards to medical and emergency centers for nurses in 2017 [7]. The main hazards that threaten health care providers include chemical hazards, physical hazards, and ergonomic hazards [8]. These risks can lead to long-term disability, reduced quality of life, absenteeism, or change in the course of nurses' professional activities [9]. Research shows that chemical and ergonomic hazards are the most common occupational hazards in the emergency room [10]. Also, according to the study of Park et al. [11], there is a positive relationship between organizational health and personal health with quality of work life. Another study showed that the highest occupational hazards in hospital nurses are related to psychological hazards such as conflict with family and reduced quality of life [12].

Work-family conflict is one of the variables that are likely to be affected by work accidents and events and affect the quality of work-life. Work-family conflict arises from two sources: interference of work issues with the family that job duties prevent the performance of family duties, interference of family issues with work, whose role in the family prevents him from performing his work duties effectively [13]. Work-life imbalances lead to high levels of stress and reduced quality of work-life [14]. According to studies, nurses working in hospitals are more exposed to work-life conflict due to their working conditions [14]. On the other hand, some studies indicate the relationship of work-family conflict with occupational accidents and reduced safety behavior [15, 16], the quality of marital relationships and the quality of parenting [10], and life satisfaction [17].

In general, the quality of work-life of ER nurses is essential in their performance and delivering service to patients and the medical system. Also, the presence of many stressful stimuli in the nursing workplace can affect their level of clinical performance. For this reason, it is necessary to pay attention to the issues and problems of emergency room nurses, especially the quality of work-life, and to provide solutions to problems related to mental health. Therefore, this study aimed to investigate the relationship between work-family conflict and the quality of work-life and the mediating role of work accidents in ER nurses.

\section{Materials and Methods}

The present study has a correlational path analysis design. This research is an applied study in terms of purpose. The study population consisted of all emergency nurses in Tehran in 2020, of whom 210 people were selected by the available sampling method. Some studies consider the acceptable number for descriptive path analysis research to be 200 people. Therefore, in this study, 210 people are supposed to provide the necessary assurance about the desired statistical power and adequacy of sampling. Because of the prevalence of coronary heart disease and its limitations, an online questionnaire was used instead of a paper-pencil. First, after determining 3 weeks for answering, the questionnaires and requests for cooperation were sent to the subjects (questionnaire link: https://panel.porsall. com/Poll/Show/4b3f1b5d915f425, date of making the questionnaire: 03/15/2021). After receiving the questionnaires, the data were analyzed with SPSS and Amos software. The criteria for entering the research were employment in the emergency room and the willingness to cooperate in this research. The subjects answered the research questions after being aware of the ethical considerations and autonomy related to attending the study.

\section{Research tools}

\section{Quality of work-life questionnaire}

Quality of work-life questionnaire was developed by Walton et al. (1973) and assessed the quality of work-life with 27 items in 8 components of fair and straw payment (3 items), safe and hygienic work environment (3 items), continuous security (3 items), organizational legalism (4 items), social dependence of working life (3 items), the general atmosphere of working life (3 items), integrity and social cohesion in the organization (4 items), and development of human capabilities (4 items). The questionnaire is scored on a 5-point Likert scale from very low $=1$ to very high $=5$. The minimum score in this test is 27 , and the maximum is 135 . The closer the score is to 135 , the more satisfied it is with the quality of work life. This questionnaire has been standardized for the first time in Iran by Allameh [18], and its reliability is 0.98 .

\section{Work-Family Conflict Scale (WFCS)}

The Carlson et al. [19] Work-Family Conflict Scale (WFCS) has 18 questions. The range of answers using 
Table 1. Correlation matrix between research variables

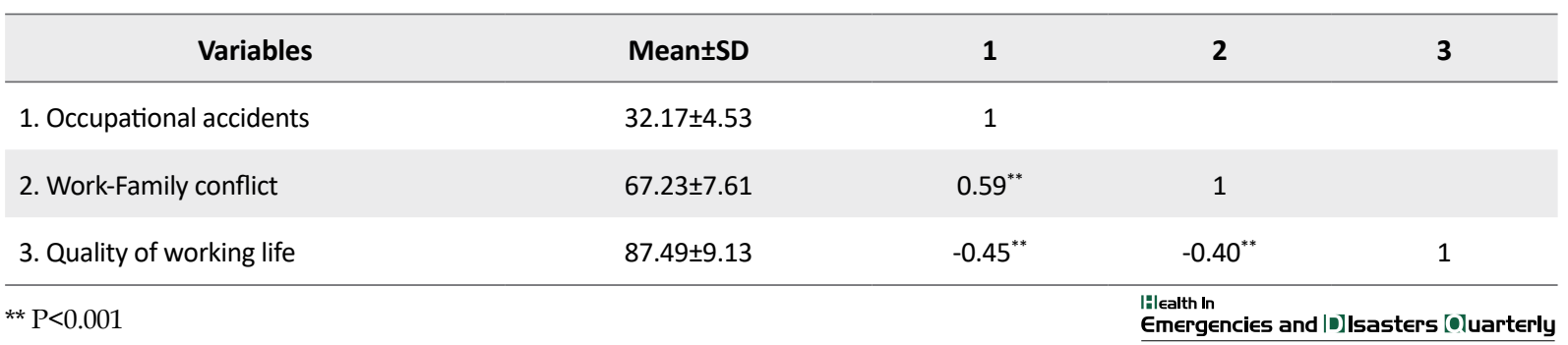

the Likert scale is from option 1 (strongly agree) to 5 (strongly disagree). A higher score on this scale indicates a more significant work-family conflict. The items of this questionnaire cover six domains of three items each. Thus, the first three articles, time-based work-family conflict, the second three articles, women-based family-work conflict, the third three articles, work-family conflict based on self-efficacy, the fourth three articles family-work conflict based on self-efficacy, the fifth article measures behavior-based work-family conflict, and the third article examines behavior-based work-family conflict. Carlson et al. [19] reported the reliability of this questionnaire by the Cronbach $\alpha$ method values between 0.78 to 0.87 . The differential validity of this tool was also investigated in the same study by examining the correlation between six factors, which was found between 0.24 and 0.83 . Only two of the correlations were above 0.6 , indicating a favorable differential validity of the instrument. Also, in the research of Fathipour and Rasoulzadeh [20], the reliability of the questions has been measured with the Cronbach $\alpha$, the value of which for the category of work-family conflict based on time is equal to 0.87 , the variable of the category of family-work conflict based on time is equal to 0.82 , category of work-family conflict based on empowerment equal to 0.88 , category of family-work conflict based on empowerment equal to 0.82 , category of work-family conflict based on behavior equal to 0.76 , category of family-work based on behavior Is calculated to be 0.86 .

\section{Occupational accidents questionnaire}

The occupational accidents questionnaire has 21 questions, and its purpose is to identify and prioritize various occupational accidents and absences caused by accidents in hospital staff. The questionnaire is scored on a 2-point
Likert scale. In the research of Hosoumi et al. [21], the content validity of the questionnaire (by the opinion of three faculty members) was confirmed. The reliability of the questionnaire was also confirmed using the retest method one week apart $(\mathrm{r}=0.69)$.

\section{Results}

According to Table 1, the relationship between job accident anxiety and work-family conflict is positive and significant, but the quality of work-life is negative and significant $(\mathrm{P}<0.01)$. The results of the correlation matrix showed that the correlation between work-family conflict variables and quality work-life is significant. Therefore, it is possible to review the model. Initially, the model fit indices were calculated, and the results of this analysis are shown in Table 2.

According to Table 2, the values of GFI, AGFI, and CFI in the present study are $0.98,0.97$, and 0.98 , respectively, which indicates the appropriate fit of the model with the data. The Root Mean Square Error of Approximation (RMSEA) for the present study was 0.06 , which can also indicate the appropriate fit of the model with the data.

As the results of Figure 1 and Table 3 show, occupational accidents, and work-family conflict have a negative and direct effect on the quality of work-life $(\mathrm{P}<0.01)$. Occupational accidents also have a positive and direct effect on work-family conflict $(\mathrm{P}<0.01)$. To investigate the mediating role of work-family conflict among occupational accidents with quality of working life, the Bootstrap command was used, the results of which are shown in Table 4.

Table 2. Model fit indices

\begin{tabular}{|c|c|c|c|c|c|c|}
\hline Indicator & $\chi^{2} / \mathrm{df}$ & $\mathbf{P}$ & GFI & AGFI & CFI & RMSEA \\
\hline Value & 1.74 & 0.005 & 0.98 & 0.97 & 0.98 & 0.06 \\
\hline
\end{tabular}




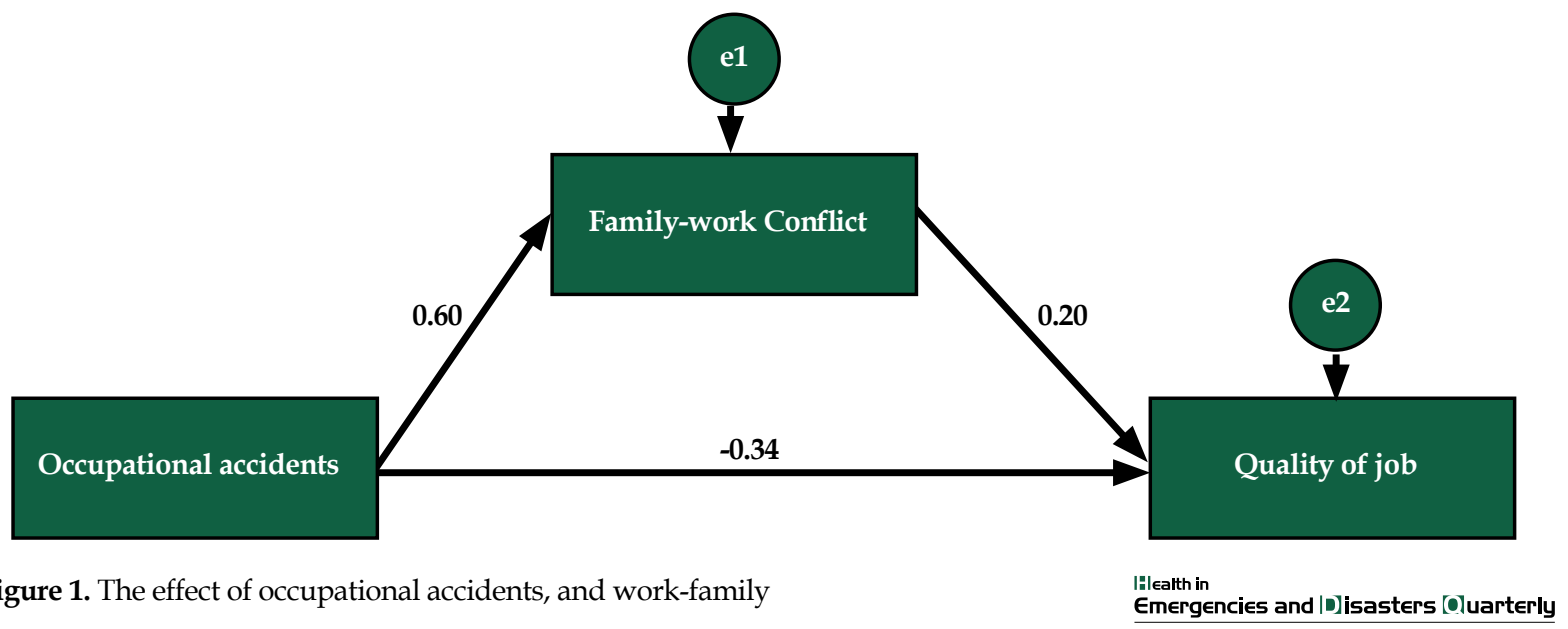

Table 3. Direct path coefficients in the model

\begin{tabular}{cccccc}
\hline \multicolumn{1}{c}{$\begin{array}{c}\text { Direction } \\
\begin{array}{c}\text { Occupational accidents affect the quality of } \\
\text { work-life }\end{array}\end{array}$} & Estimated Value & Standard Value & S.E & C.R & P \\
\hline $\begin{array}{c}\text { Occupational accidents on work-family conflict } \\
\text { Work-family conflict on quality of work-life }\end{array}$ & 0.88 & -0.34 & 0.15 & 5.58 & 0.001 \\
\hline & -0.25 & 0.60 & 0.07 & 7.01 & 0.001 \\
\hline
\end{tabular}

As shown in Table 4, work-family conflict mediates between occupational accidents and quality of work-life.

\section{Discussion}

This study aimed to investigate the relationship between occupational accidents and quality of work-life mediated by work-family conflict in ER nurses. The results showed that occupational accidents have a positive and direct effect on work-family conflict. These results are in line with the findings of Pereira et al. [22], Osca and Lopez [23], Malakoutikhah et al. [24], and Jamshidian et al. [25]. Occupational accidents lead to mental imbalance and psychological trauma in nurses, and this stress can be drawn in the process of the mechanism of transfer to the work-family environment. On the other hand, the crisis caused by accidents can lead to serious psychological and physical damage, the rehabilitation of which is time- consuming and requires care, which will challenge the family. In the COVID-19 epidemic, all service personnel is at risk, and the emergency department suffers more damage because of being on the front line. This condition will drag stress from the work environment to the family environment and force some personnel to evade work. Therefore, considering the relationship between occupational accidents and the perception of stress in the family [12], it seems logical that occupational accidents are related to work-family conflicts of ER nurses.

Research findings also show a relationship between occupational accidents and quality of work-life. These results are consistent with the findings of previous research $[26,27]$. One of the essential dimensions of quality of work-life is the existence of job security, and these two variables are interrelated. According to Abraham Maslow, security is one of the basic needs, the fulfillment of which is a precondition for satisfaction and quality of

Table 4. Estimation of indirect paths in the model using bootstrap

\begin{tabular}{|c|c|c|c|c|c|c|}
\hline \multicolumn{3}{|c|}{ Direction } & \multirow{2}{*}{ Estimated Value } & \multirow{2}{*}{ Upper Limit } & \multirow{2}{*}{ Lower Limit } & \multirow{2}{*}{ Sig. } \\
\hline Predictive Variable & Intermediate Variable & Criterion Variable & & & & \\
\hline $\begin{array}{l}\text { Occupational Ac- } \\
\text { cidents }\end{array}$ & Work-family conflict & $\begin{array}{l}\text { Quality of work- } \\
\text { life }\end{array}$ & -0.11 & -0.18 & -0.05 & 0.01 \\
\hline
\end{tabular}


life. Occupational accidents can result in physical or psychological injuries that reduce the quality and satisfaction of working life. Therefore, considering the urgency and importance of dealing with accidents and the different consequences of accidents in work life, it seems logical that there is an inverse relationship between occupational accidents and the quality of work-life of ER nurses.

The study's main result shows that the mediating role of work-family conflict between occupational accidents and quality of work-life was confirmed. A literature review shows that no research has been conducted to investigate the relationship between occupational accidents and quality of work-life mediated by work-family conflict in ER nurses. But the results of this study on the relationship between occupational accidents and work-family conflict $[22,23]$ and occupational accidents with quality of worklife $[26,27]$ and finally, work-family conflict is consistent with the quality of work-life [28-30]. Work-related accidents alone can impair the quality of work-life. Still, the association of these events with work-related family life conflict in connection with work can add to the burden, and their combining can have a devastating effect on the quality of work life. On the other hand, safety always comes before work, and accidents lead to a feeling of insecurity that this perception of insecurity can cause the family to be stressed and take conflicting positions regarding work. In such situations, family conflict can play a role in the severity of the relationship between occupational accidents and the quality of work-life.

One of the limitations of this study is using online sampling and self-report scales instead of doing in-depth research on the effects of gender, age, education, and the level of coping and self-management skills in the face of accidents and disasters. It is suggested that in further studies, qualitative methods be used simultaneously with quantitative ones to achieve a deeper understanding of the relationship between these variables. The role of gender, age, education, skills, and self-management variables in the relationship between family conflict, work accidents, and quality of work-life should also be examined. In this study, ethical considerations such as voluntary participation in the research and keeping confidential the subjects' personal information were considered.

\section{Ethical Considerations}

\section{Compliance with ethical guidelines}

The participants were informed of the purpose of the research and its implementation stages. A written consent has been obtained from the subjects. They were also as- sured about the confidentiality of their information and were free to leave the study whenever they wished, and if desired, the research results would be available to them. The Helsinki Convention was also observed.

\section{Funding}

This research did not receive any grant from funding agencies in the public, commercial, or non-profit sectors.

\section{Authors' contributions}

All authors equally contributed to preparing this article.

\section{Conflict of interest}

The authors declared no conflict of interest.

\section{References}

[1] Baysal HY, Yildiz M. Nursing's job life quality's effect on job satisfaction. International Journal of Caring Sciences. 2019; 12(2):1056. http://www.internationaljournalofcaringsciences.org/docs/51_hasret_original_12_2.pdf

[2] Lawati MH, Dennis S, Short SD, Abdulhadi NN. Patient safety and safety culture in primary health care: A systematic review. BMC Family Practice. 2018; 19(1):104. [DOI:10.1186/ s12875-018-0793-7] [PMID] [PMCID]

[3] Akar H. The relationships between quality of work life, school alienation, burnout, affective commitment and organizational citizenship: A study on teachers. European Journal of Educational Research. 2018; 7(2):169-80. [DOI:10.12973/ eu-jer.7.2.169]

[4] Swamy DR, Nanjundeswaraswamy TS, Rashmi S. Quality of work life: Scale development and validation. International Journal of Caring Sciences. 2015; 8(2):281. http://www.internationaljournalofcaringsciences.org/docs/6_swamy.pdf

[5] Zadi Akhule O, Lotfi M, Memarbashi E, Jafari K. [The relationship between occupational hazards and intention to leave the profession among perioperative and anesthesia nurses (Persian)]. Nursing and Midwifery Journal. 2020; 18(7):53242. [DOI:10.29252/unmf.18.7.532]

[6] Ndejjo R, Musinguzi G, Yu X, Buregyeya E, Musoke D, Wang JS, et al. Occupational health hazards among healthcare workers in Kampala, Uganda. Journal of Environmental and Public Health. 2015; 2015:913741. [DOI:10.1155/2015/913741] [PMID] [PMCID]

[7] Baig NN, Aleem SA. Occupational Hazards Among Dental Surgeons In Karachi. Journal of College of Physicians and Surgeons Pakistan. 2016; 26(4):320-2. [PMID]

[8] Isara AR, Ofili AN. Prevalence of occupational accidents/Injuries among health care workers in a federal medical centre in Southern Nigeria. West African Journal of Medicine. 2012; 31(1):47-51. [PMID] 
[9] Lin L-Y, Juan C-W. [A systematic review of the literature: Risk factors and strategies for occupational hazards in hospitals (Chinese)]. Chinese Journal of Occupational Medicine. 2015; 22(2):71-88. https://www. airitilibrary.com/Publication/alDetailedMesh?doc id $=10233660-201504-201504290008-201504290008-71-88$

[10] Mousavi B, Mozhde S, Yazdannik A. [Investigating occupational hazards of the operating room and the causes of its occurrence in the operating room nurses of al-Zahra Medical Center (Persian)]. Journal of Sabzevar University of Medical Sciences. 2020; 27(2):287-93. http://jsums.sinaweb.net/article_1298.html?lang=en

[11] Park JH, Cho YS, Lim SR. Analysis of factors affecting the quality of work life of dental hygienists based on the culturework-health model. Journal of Dental Hygiene Science. 2018; 18(1):32-41. [DOI:10.17135/jdhs.2018.18.1.32]

[12] Shahabinejad M, Ghiasi AR, Ghaffari M, Barkhordar A, Soltani Poorsheikh S. [Identify occupational hazards of each of the occupational groups in a military hospital (Persian)]. Journal of Nurse and Physician Within War. 2017 5(15):31-7. https://www.sid.ir/en/journal/ViewPaper. aspx?id=593295

[13] Kocalevent R, Pinnschmidt H, Selch S, Nehls S, Meyer J, Boczor S, et al. Burnout is associated with work-family conflict and gratification crisis among German resident physicians. BMC Medical Education. 2020; 20(1):145. [DOI:10.1186/ s12909-020-02061-0] [PMID] [PMCID]

[14] Fang YX. Burnout and work-family conflict among nurses durning the prepartion for reevaluation pf a grade A tertiary hospital. Chinese Nursing Research. 2017; 4(1):51-5. [DOI:10.1016/j.cnre.2017.03.010]

[15] Chu F, Guo M, Liu S, Chen S. Work-family conflict, personality, and safety behaviors among high-speed railway drivers. Journal of Transportation Safety \& Security. 2020; 12(9):1147-63. [DOI:10.1080/19439962.2019.1579289]

[16] Smit TD, Hughes K, Dejoy DM, Dyal MA. Assessment of relationships between work stress, work-family conflict, burnout and firefighter safety behavior outcomes. Safety Science. 2018; 103:287-92. [DOI:10.1016/j.ssci.2017.12.005]

[17] Beit Mashal B, Heidarie A, Arshadi N, Askary P. [The causal relationship between neuroticism, job stress and workfamily conflict with turnover intention and life satisfaction through mediating role of job burnout in employees of Karoun oil and gas company (Persian)]. Knowledge \& Research in Applied Psychology. 2020; 21(3):25-39. http:/ /jsr-p.khuisf. ac.ir/article_667713_en.html?lang=en

[18] Allameh M . [Development of walton quality of work life model based on Islamic values (with emphasis on Nahj al-Balaghah) and determining its impact on reducing psychological stress (Persian)] [MSc, thesis]. Tehran: Tarbiat Modares University, Faculty of Humanities; 1999. https:// parseh.modares.ac.ir/thesis/1032090

[19] Carlson D, Kacmar K, Williams L. Construction and initial validation of a multidimensional measure of workfamily conflict. Journal of Vocational Behavior, 2000; 56(2):249-76. [DOI:10.1006/jvbe.1999.1713]

[20] Fathipoor P, Rasoulzadeh Aghdam P. [Study of workfamily-work conflict among women working in government institutions in Tabriz (Persian)]. Sociological Studies. 2010 9(36):31-48. https://www.sid.ir/fa/journal/ViewPaper. aspx?id $=466147$
[21] Hasoumi M, Jouyani Y, Asadi H, Khakian M, Aryankhesa A. [Staff occupational accidents and the resulted absence in hospitals of Tehran and Iran universities of medical sciences; 2013 (Persian)]. Occupational Medicine. 2016; 7(4):4-13. https://www.sid.ir/en/journal/ViewPaper.aspx?ID=506451

[22] Pereira KT, Silva AC, Silva LF. Prevalence study on selfdeclared work accidents in areas covered by family health strategies: A cross-sectional study. Sao Paulo Medical Journal. 2020; 138(1):79-85. [DOI:10.1590/1516-3180.2019.0325. r1.06112019] [PMID]

[23] Osca A, López-Araújo B. Work stress, personality and occupational accidents: Should we expect differences between men and women? Safety Science. 2020; 124:104582. [DOI:10.1016/j.ssci.2019.104582]

[24] Malakoutikhah M, Karimi A, Hosseini M, Rastgarkhaled A. [Modeling of relationship between work-family conflict and occupational accident in a steel manufacturing industry (Persian)]. Journal of Health and Safety at Work. 2017; 7(1):7784. https://jhsw.tums.ac.ir/browse.php?a_code=A-10-1 $46 \&$ sid $=1 \&$ slc_lang=en

[25] Jamshidian Y, Kiani A, Dargahi S. Relationship of cognitive emotion regulation and meaning in life with health anxiety among emergency nurses. Health in Emergencies and Disasters. 2018; 3(4):199-206. [DOI:10.32598/hdq.3.4.199]

[26] Laal F, Modrek MJ, Balarak D, Mohammadi M, Rakhshani M, Rigi N. Relationship between quality of life and occupational accidents in southeast of Iran (Zahedan). Global Journal of Health Science. 2017; 9(2):112-8. [DOI:10.5539/gihs.v9n2p112]

[27] Nazari J, Dashti M. [Study the impacts of occupational accidents on the quality of working life among workers in a steel company (A case study) (Persian)]. Health and Safety at Work. 2019; 9(1):73-83. https://jhsw.tums.ac.ir/browse. php?a_id $=6040 \&$ sid $=1 \&$ slc_lang $=$ en

[28] Dursun E. The relationship between work-family conflict and work life quality of air transportation sector employees. Revista Argentina de Clínica Psicológica. 2020; 5:1179-84. [D OI:10.24205/03276716.2020.1113]

[29] Zandian H, Sharghi A, Moghadam TZ. Quality of work life and work-family conflict: A cross-sectional study among nurses in teaching hospitals. Nursing Management. 2020. [DOI:10.7748/nm.2020.e1881] [PMID]

[30] Ashar A, Harsanti I. Hubungan work family conflict dengan quality of work life pada karyawan wanita perusahaan swasta. Jurnal Psikologi. 2016; 9(2):120-31. https:// ejournal. gunadarma.ac.id/index.php/psiko/article/view/1550 